\title{
Blended Learning System in The Pandemic Era: How is The Integration of Science Learning Creative Thinking Skill in Elementary School ?
}

\author{
Ferrinda Prafitasari ${ }^{1 *}$, Sukarno $^{2}$, Muzzazinah $^{3}$ \\ \{ferrindaprafitasari@student.uns.ac.id ${ }^{1}$, sukarno57@staff.uns.ac.id ${ }^{2}$, yayin_pbio@ fkip.uns.ac.id ${ }^{3}$ \} \\ Universitas Sebelas Maret, Surakarta, Indonesia ${ }^{1,2,3}$
}

\begin{abstract}
The covid-19 pandemic forced the government to implement new learning refers to a blended learning system. This research analyzes the integration of creative thinking skills science learning using composite learning systems in elementary schools during the covid-19 pandemic. Research case study qualitative with descriptive percentages. Collected data: observation, interviews, documentation, and questionnaire. Data validity: sources and triangulation techniques. Data analysis techniques using: collection, reduction, presentation, and conclusions. The results of research integration creative thinking skills in science learning using blended learning system implementation low with $(\mathrm{Mo}<\mathrm{Md}<\mathrm{Me})$, mean $=13.84$ and frequency distribution of the majority $47.37 \%$. Percentage learning authenticity indicator $38.50 \%$, flexible $36.90 \%$, elaborative $24.60 \%$. Constraints: limited learning difficulty developing new thinking, writing answers to similar books, and answering questions not detailed. Efforts: apperception, freedom of discussion during online and face-to-face learning, development of High Order Thinking Skill (HOTS) relevant life, strengthening concepts by reading before understanding, and maximizing WhatsApp features including video calls and voice notes.
\end{abstract}

Keywords: creative thinking skills, science, blended learning system

\section{Introduction}

Pandemic COVID-19 caused changes in the education sector. Education is required to adapt to pandemic conditions in COVID-19, and creative thinking skills must be developed under any circumstances [1], [2]. The spread of COVID-19 has an impact on various fields in the world, including education. Therefore, a policy was issued to suppress the spread of the virus with PSBB (large-scale social restrictions). Home study policy to reduce social activities outside the home [3], [4]. Learning is encouraged to be online at the same time. Teachers and educators must undergo the ongoing massive migration from conventional face-to-face education to distance education [5]-[7]. [3], [8], [9]. The spread of COVID-19 is increasingly worrying, so that the learning process, which usually includes class meetings, was transferred from home to online meetings or work (WFH). Technology in the 21 st century is keying to implementing various activities where technology changes aspects of life with e-learning [10]. The educational industry has to adjust the learning process as a result of the COVID-19 pandemic. The learning of COVID-19 is done via the use of online technologies.

Science is a system that derives evidence from the universe through everyday observations and experiments on life and natural phenomena that meet the needs of students. The content is 
the environment but complex for students to understand, and the material is complicated preliminary discussion. Science is a system that derives evidence from the universe through everyday observations and experiments on life and natural phenomena that meet the needs of students. Alternative to overcome these difficulties to strengthen the integration abilities of creative thinking learning because of the importance of mastering the material as the basis for further education, if in elementary school the ability to understand the material has not been learned well, it will not be easy to understand the following material. Educators can create learning programs that focus on creative thinking skills to help students build problem-solving skills [13]-[16]. Science instruction is very near to kids, is understandable by students, and the materials are complicated. Science is a system that develops universe proof from daily observation and experimentation of living and natural events that suit students' requirements.

During the COVID-19 pandemic, creative thinking skills must still be integrated into learning as one of the 21st-century competencies that must be included in abstract science material that cannot be observed directly as 21 st-century skills. States that training is a systemic attempt to build a learning process for students to develop themselves in religious, spiritual strength actively, personality, self-control, and intelligence needed by themselves, society, and the state. At a basic level, 21st-century skills are not yet fully integrated into learning. Ideally, integrating creative thinking talents as 21 st-century skills can increase students' motivation and understanding. Students need to be encouraged to explore information and build meaning in a class by getting used to thinking creatively. The development of creative abilities or innovation will produce a helpful breakthrough. The ability to think creatively and work creatively is strengthened, stating that creative skills can be achieved by using techniques to create broad ideas to gain new ideas [11]. New ideas are then elaborated, analyzed, and evaluated to improve and maximize creative thinking. Creative thinking is then developed, implemented, and communicated to others. Creativity and innovation will be easier to create if students have the opportunity to think divergently (branching). Thinking outside of existing habits and involving new ways of thinking, conveying new ideas and solutions, asking unusual questions, and proposing likely answers must be developed and accustomed to students. Blended learning or blended learning systems can improve pupils' inventiveness solving a problem because encouragement of students always to think [12]. The goal is that, throughout the covid 19 pandemics, schools will continue to incorporate creative thinking abilities according to skills from the 21 st century. Creativity facilitates creating something new to solve a problem in everyday life, assisted by blended learning during the Covid-19 pandemic.

Based on observations that occurred at SDIT Mutiara Boyolali, they have implemented a blended learning system. However, in actuality, it still exists many obstacles that teachers and students still experience because the system is being implemented for the first time in an emergency of the COVID-19 pandemic. Time constraints, while online learning constraints are the limited technological capabilities of teachers and parents of students. There are many learning platforms available, but the teacher only informs the material through the WhatsApp platform, and the teacher sends more assignments than the material. At this time, worried about creative thinking, Students who consist of several aspects, including original, flexible, and elaborative, will be hampered. Whereas in science learning, these things must be mastered by students so that education runs as it should. Teachers and students have technological limitations in the distance learning process [20]. The preliminary findings show that aspects of creative thinking skills in the form of originality, flexibility and complexity indicate potential obstacles to their being integrated well in primary schools. So it is necessary to evaluate them to reduce obstacles to implementing a blended system of learning on thought creative skills. They are 
considering that the blended learning approach was initially adopted during the COVID-19 pandemic in primary schools.

Minimizing pandemic problems in education by using alternative training. The new average reform era in the field of education began with e-learning and continued to blended learning. Schools can also adopt a composite learning system according to the requirements and, at the same time, implement a teaching system [17]. Learning that combines face-to-face and blended learning techniques is termed the online, which is a superior method to combine various learning methods, pedagogical approaches, and internet technology [18], [19]. Solutions to include creative science thinking skills to build student thinking with a combined system of learning. It is therefore important to grasp the material in science so that the material may be understood. In the pandemic COVID-19, schools can use a blended learning system with various methodologies to incorporate creative thinking abilities into the student throughout the Pandemic of the COVID-19.

The role of instructors and students may alter before implementing the blended learning system based on research, and e-learning is engaging because it increases the clarity of learning to individuals, the learning process, and feedback [21]. This research focuses on blended learning systems without specifically for creative thinking skills as 21 st-century skills. Blended learning system including digital and face-to-face training can assist the development of skills [22]. The difference between this research from previous research is the subject and focus of the material. The issues in the previous study were that students and were not focused on learning science, while this study focused on the scope of elementary schools and learning science. Technological advances are an essential part of enhancing learning quality and results in research. However, previous research was not carried out during a pandemic emergency, so that the results would be different from those in a crisis. The study outcomes are backed by other literature sources accessible online, and information is discussed in face-to-face, offline meetings. A mixed system of learning is called that mixture of online and offline learning. The learning strategy blends face-to-face learning with online learning. The learning idea offers technology for integrating face-to-face learning and online learning approaches to help instructors through their learning processes [23]. The distinction between this study and past studies is the research theme and focus. This research focuses on primary and scientific students with components of knowledge in the form of creative thinking abilities in the 21st century.

This urgency of the research was carried out because it can consider alternative learning systems during the COVID-19 emergency. The results of this study have implications for finding solutions to improve creative thinking skills in science learning with blended learning system learning to be more effective. The recommendation in this study is that teachers are more creative in implementing blended learning system learning strategies so that the success of creative thinking skills in learning science for students can be adequately achieved. Given the relevance of science learning materials and creative thinking abilities, research into integrating creative thinking skills with a combined learning system is required. In the present COVID-19 pandemic situation, a hybrid learning system offers a new solution.

\section{Research Methods}

The research was carried out with a qualitative style of investigation. Descriptive is the research design employed. Study aim to evaluate the integration of creative thinking skills in scientific learning uses blended learning. The research design is presented in figure 1: 


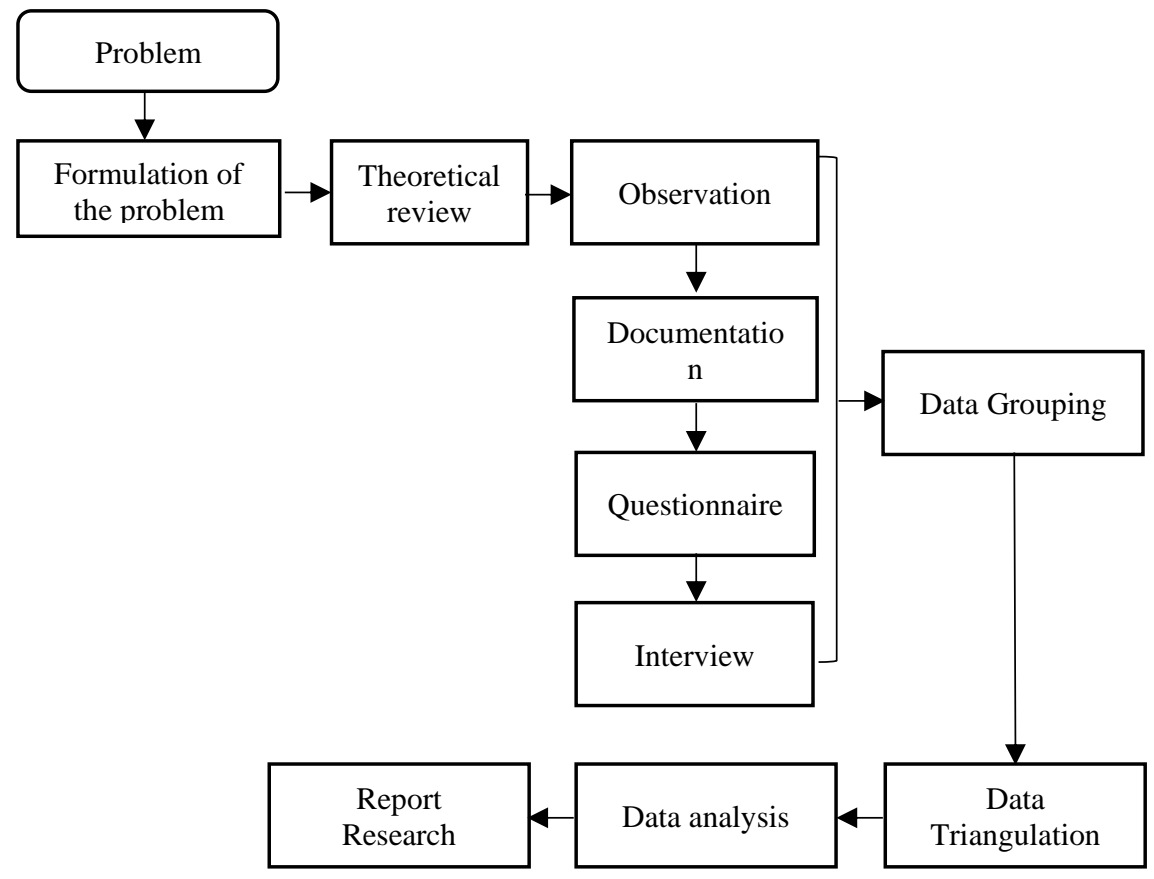

Fig. 1. Research design

Observations and research were carried out in February-May 2021. Data collecting strategies in the study included observation for direct data acquisition, a questionnaire to reinforce the respondent's knowledge on other things he knows, documentation in the form of work data for the student, and a half-structured interview to find out more often. The subjects interviewed in this study were 19 students, teachers, and principals at SDIT Mutiara Boyolali, Central Java.

Table 1. Instrument integration of science learning creative thinking skill in elementary school with blended learning system

\begin{tabular}{ll}
\hline Aspect & Description \\
\hline Original & $\begin{array}{l}\text { Finding old concepts and writing new ones } \\
\text { Explaining new approaches based on the concept } \\
\text { Solve problems in new ways from unusual combinations of } \\
\text { familiar elements. }\end{array}$ \\
Flexible & $\begin{array}{l}\text { I am giving an interpretation to an image, story, or problem. } \\
\text { Explain the various combinations of interpretations with the } \\
\text { elements found. }\end{array}$ \\
& $\begin{array}{l}\text { Classify things according to different divisions (categories). } \\
\text { Elaborative }\end{array}$ \\
& $\begin{array}{l}\text { We are looking for a deeper meaning to the answer or problem } \\
\text { solving by performing detailed steps. } \\
\text { Develop found ideas or concepts found in detail. }\end{array}$ \\
\hline
\end{tabular}


Descriptive calculations of percentages are then interpreted into sentences. Calculate the rate by using the following percentage formula:

Information:

$$
\mathrm{P}=\frac{f}{n} \times 100 \%
$$

$\mathrm{P}=$ percentage

$f=$ the number of frequencies of each answer chosen by the respondent

$n=$ the number of frequencies or the number of individuals (Arikunto, 2016).

The score data is the total score of all aspects of creative thinking skills in science learning using the blended learning system PAP (Based Reference Assessment), which will change the average value.

Table 2. Table rules for converting average and ideal standard deviations on a five scale

\begin{tabular}{ll}
\hline Score Range & Category \\
\hline $24 X<32$ & Very high \\
$19 X<23$ & High \\
$14 X<18$ & Medium \\
$9 X<13$ & Low \\
$0 X<8$ & Very low \\
\hline
\end{tabular}

Triangulation of sources and techniques is the validity of the data, The verification of data trustworthiness utilizing several methodologies, including observations, documents, interviews and questionnaires. In contrast, triangulation of data sources came from multiple sources. Data analysis techniques by way of data are arranged, sorted, grouped, then classified by model, covering data, data reduction, presentation and conclusion of data according to Milles \& Huberman. Data were examined in the form of tests based on the rubric supplied. Then the data was described and then analyzed by determining the type of descriptive percentage obtained by each indicator.

\section{Results and Discussion}

The integration of creative thinking skills in learning is important because it trains students to produce many varied ideas, develop ideas into more details that come from themselves. Creative thinking skills in science learning with a blended learning system are low. The analysis of Scientific education with a combined learning method achieves innovative thought talents for 19 students is presented in polygons, as shown in Figure 1. 


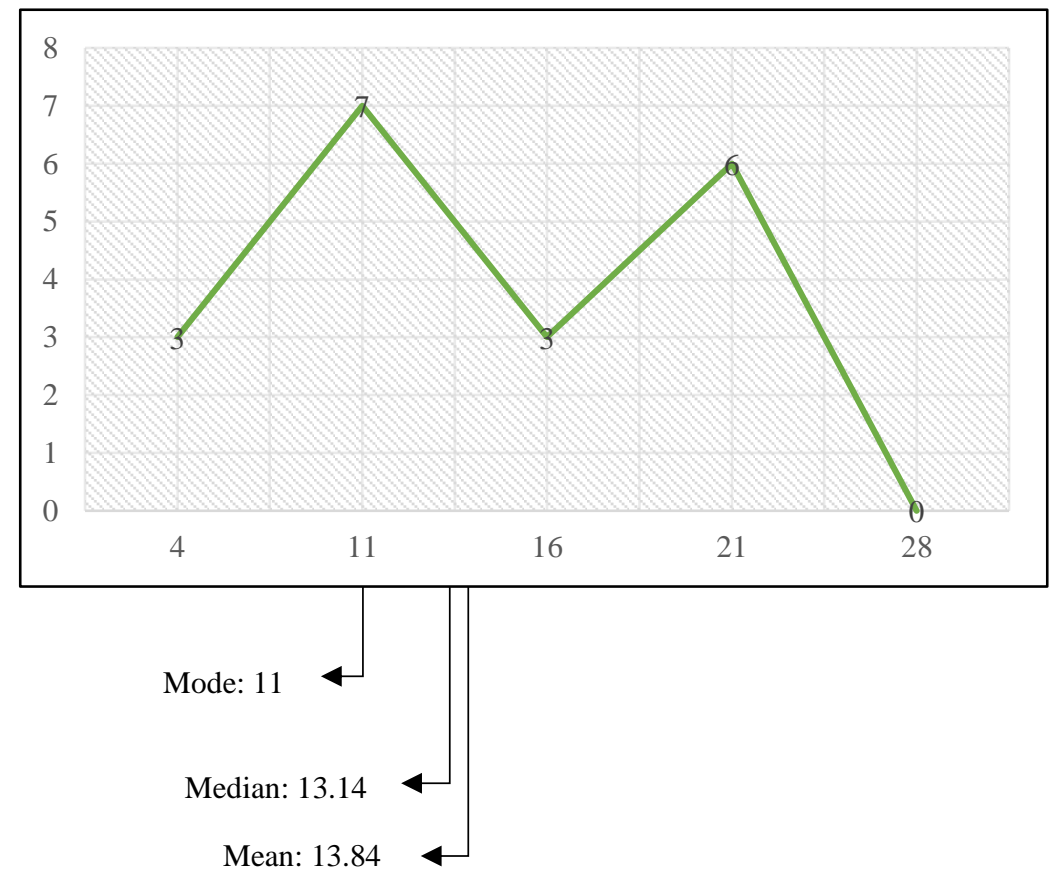

Fig. 2. Creative thinking skill polygon data in science learning using blended learning system

Based on known polygon curves (Mo $<\mathrm{Md}<\mathrm{Me}$ ), a positive squint curve means most scores tend to below. Mean $=13.84$ changed by PAP in table 3 , the creative thinking skills with a blended learning system are therefore low.

Table 3. Frequency distribution percentage of creative thinking skills in science learning using a blended learning system

\begin{tabular}{lll}
\hline Category & Frequency & Percentage \\
\hline Very high & - & - \\
High & 6 & $31.60 \%$ \\
Medium & 3 & $15.78 \%$ \\
Low & 7 & $36.84 \%$ \\
Very low & 3 & $15.78 \%$ \\
& 19 & $100 \%$ \\
\hline
\end{tabular}

The learning process with projects significantly influences critical and creative thinking in blended learning system learning [24]. The first education of prospective professors should entirely be focused on good knowledge of their topic, mastery of different approaches, and creative thinking development. Science training offers many chances to improve intellectual abilities such as analysis and synthesis, comparison and submission, information management and teamwork. The main aim of various teaching techniques is to create fresh, creative ideas at the educational level of these talents [25]. Creativity and the development of thinking skills of 
the scientific method of the kid, the lecturers' attitude, the level of practice and activity given to kids is crucial for school education [26]. Schools, teachers, parents, communities, and policymakers can make a difference in enhancing creativity. Creative skills will encourage students to be successful because they can develop something new using a combination learning or blended learning system to maximize WhatsApp features, including video calls and voice notes.

Blended learning on creative abilities utilizes a structural equation model to verify certain factors that may benefit instruction in education [27]. Using a blended learning system can also be used as an alternative during the pandemic COVID-19 to build the creative thinking talents of pupils yet. Learning with blended learning is a competent instructor in the classroom and is designed to offer his pupils knowledge of creative thinking. At some periods, students are independent and accountable for their education. The environment of e-learning will make students play an active part in their knowledge [28]. The COVID-19 pandemic involves education both online and personally, or with a combination of learning blended learning system approach - each of these three days of online and offline learning alternates. The combined classroom learning model reverses the teachers delivery of learning materials from the classroom to watching the delivery of learning materials through videos at each student's home.

Face-to-face classroom teaching is utilized for group debates, resolution and collaborative projects between students and their peers. Instruction from the teacher has become theoretical knowledge and understanding of problems that must be solved when entering or attending faceto-face learning sessions in class [29]. In one day, face-to-face learning can be completed in three hours. Learn online with WhatsApp, take advantage of all available features such as voice notes, video calls, and time flexibility.

E-learning systems for the promotion of creative thinking amongst students in a virtual learning environment through communication between students, teachers, students and students, explicit knowledge, collaboration and the gathering of knowledge, existing online tools for designing the system e-learning, e-learning model is essential to improving creativity [30]. Learning is attempted to make students feel comfortable and happy by being continuously introduced to the real-life atmosphere. Face-to-face and online classroom performances offer a broader opportunity to investigate and explain to discover different thoughts [12]. A blended learning system enhances creative thinking because it allows students to think efficiently, starting with researching interesting logical problems, generating imaginations according to the ideas learned, and completing exercises.

\subsection{Original}

All students have these skills to develop new ideas through face to face and online learning, although they vary among individuals. Creative thinking abilities involve scientific ideas and skills in processes, such as discovering the material from which an object is created, reasoning about links between causes and effects and the use of measuring instruments [26]. The following are the results of the student's answers to the questionnaire about creative thinking skills in the original aspect, presented in the following graph: 


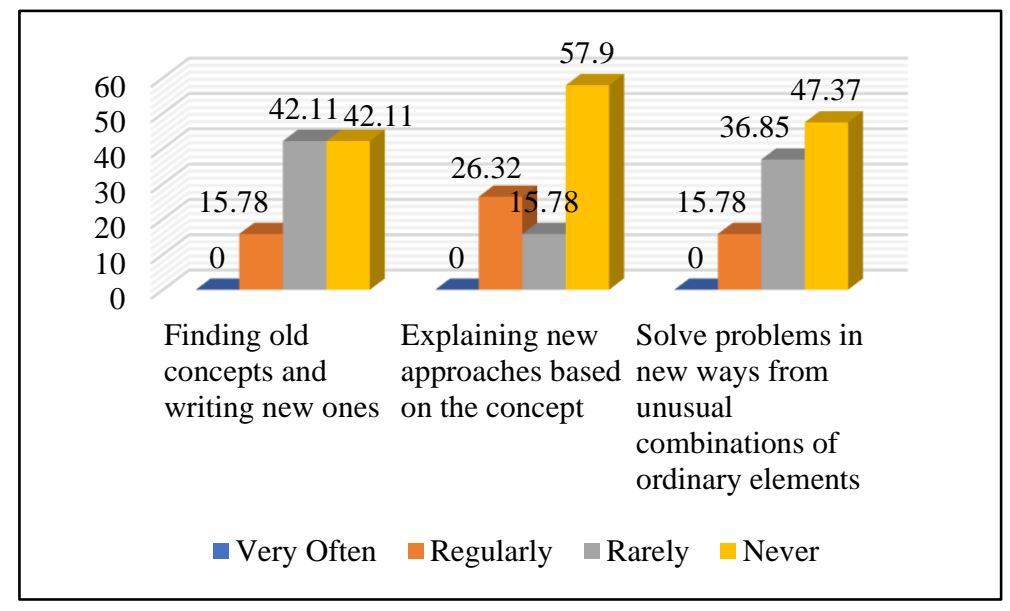

Fig. 3. Results of student questionnaire answers on original aspects

The highest percentage of original aspects in the graph above is the indicator of choice never with a rate of $49.12 \%$. When learning science with the blended learning system has not been well integrated. While in understanding the overall creative thinking skill aspect of the original $38.50 \%$.

Originality or authenticity is an aspect of creative thinking skills. In this aspect, it has been applied in learning. Students have not been able to find old concepts and write new ideas and tend to write precisely the explanation according to the book. Most students find it challenging to solve problems that require solutions obtained from original thinking directly, which is because they tend to memorize concepts. The solution is that teachers and parents More customized assistance for the learning, autonomous and collaborative learning [31]. General students of primary school were allowed to find their most creative answers, but aspects, completeness, practicality showed that Students judged rather than ignored completeness. Students may consider all aspects but choose First because most cognitive work and time are needed for such thoughts [32]. It is highly essential to think about new ideas. When creative thinking grows and ideas are born, creative, imaginative, material visions and know-how are generated by creating information.

Learning to provoke the sensitivity of students to bring up new things is done by the teacher without asking questions related to the material in everyday life thoroughly because of the limited time to study. Providing explanations with new approaches based on concepts has not been fully achieved by students because they do not explain concepts in detail and are only based on books without being associated with everyday life. Emphasis on skill development is essential to enhance knowledge-building ability by improving students' skills [33]. Limited study time and explanations do not explain an idea in detail and only books can help instructors work with solutions to develop learning areas that promote the mutual learning process.

Solving problems in new ways from unusual combinations of common elements, not all students have fully achieved this because students only explain the details in the book without any blends with existing features in daily life. According to the book, the low score of most of the students in answering the questions is probably due to their failure to describe the idea clearly and entirely tendency respond as is usually explained during the class. Relatively weak adaptation was found in school students who were not accustomed to using their creativity and thoughts towards others. Rote learning is the pedagogical approach to education in such schools. 
The solution is to ask them to voice their own opinions or views, not just spit out the information provided by the teacher with innovation [34]. This results in low imagination in creating a new idea. Only a few students gave answers by mentioning the expected ideas, despite the lack of complete and clear explanations. These obstacles occur due to limited learning time due to the covid 19 pandemic because blended learning system learning is carried out in a limited time so that learning difficulties develop new thinking. The use of inappropriate learning models can lead to unsatisfactory results. Learning models and media must help teachers and students establish good interactive relationships to understand the teaching material and solve problems. The model that can be applied is project-based learning. Solving issues orally and in writing, creativity always provides something new and meaningful following everyday life before the teacher implements education [35]. Students can not describe the specifics of a book without mixing up existing characteristics of daily life to have student comments and models interactive media learning.

\subsection{Flexible}

Flexibility is a creative thinking talents component. In this respect, face-to-face and online learning have been utilized. All students have these abilities, but it varies between students. The outcomes of the student are as follows answers to the questionnaire about creative thinking skills in the flexible aspect, presented in the following graph:

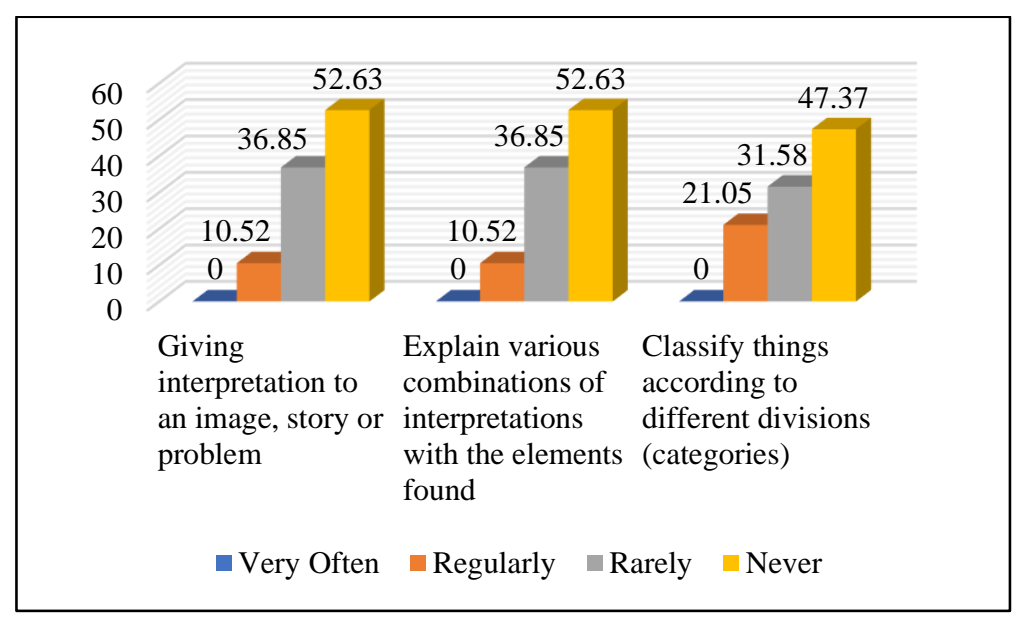

Fig. 4. Results of students' questionnaire answers on flexible aspects

The highest percentage of flexible aspects in the graph above is the indicator of choice never with a rate of $50.87 \%$. When learning science with a blended learning system, the elastic elements have not been well integrated. Meanwhile, in the overall learning of creative thinking skills, the flexible aspect is $36.90 \%$.

The learning teacher gives written assignments, and the teacher asks students to write science material based on categories. Students carry out the process of working on the task by working on the questions in the textbook accompanied by explanation reasons for answering. 
When learning online, the functions given are about the material by doing simple experiments and then working on questions about the investigation, which then collects the results in the form of photos. It fits project assignments given to students have stimulated them to understand the concepts learned in creating products [24]. However, in practice, it is not entirely owned by students. Students have not been able to provide an interpretation of an image, story, or problem, Interpret an article's conclusion or link concepts according to different viewpoints, as the conduct of a person with flexible think talent is enough to produce many interpretations of a picture, history or problem, which varies. This is inversely proportional to the application of blended learning, and the results show that the effect is flexible, runs in learning activities [36]. This is due to the pandemic situation, which limits the time in the implementation of blended learning. A solution that can be used as a reference is to use a learning model that applies a simple experiment. Which can improve knowledge mastery, help students apply knowledge to solve problems, and actualize scientific literacy and creativity competencies [37]. Creative thinking skills taught in relevant content will encourage students' thinking skills into creative thinking habits while playing with ideas and processing content information in various ways. Students will feel joy in learning, find meaning and personal relevance in [24]. Interpret a picture, narrative, or issue. Interpret the conclusion of an article that the pupil does not possess the skills. An alternative approach that improves knowledge helps with small experiments solve scientific problems and creativity.

Explaining various combinations of interpretations accompanied by elements found that students do not have because they tend to write according to what is in the book and do not develop arrangements other than textbooks. Students have not been able to relate information in real life and those obtained from the school by providing various possible answers. Even though the ability students can strengthen and develop intellectual skills associated with acquiring creative thinking to connect their work to other knowledge areas. The solution is to make systematic observations of reality, investigate the spot, and collect information [25]. Students could not integrate facts about actual life with those obtained by providing alternative answers with solutions for which rigorous, realistic observations, location investigation and information collecting might be required.

Classifying things according to different divisions (categories) cannot be wholly owned by students. Students were asked to describe problems related to problems by evaluating the experimental process presented in the issue. Students better understand the practical steps that are written in the task accompanied by pictures. The teacher Provide closed questions so that it is difficult to develop creative thinking. Creative thought is a process that provides several possible answers when answering specific questions. Therefore, the project method is very relevant to improve creative thinking skills. Students are happy and interested in the completed project [38]. Methodological processes are relevant to the long-term development of practices and the end of the opening of methods.

Answers from students show that one piece of knowledge has not been related to information from various fields. Students must link their learning experiences from past to present. Teachers should assist pupils in clarifying their concepts. Online and personal learning freedom to talk is required to improve learning towards a relevant life to the High Order Thinking Skill (HOTS) issue. Learners are encouraged to increase their conceptual knowledge and to implement their knowledge. Contribute to the learning results of scientific students, including academic success, creative thinking and research. Instructors are called upon today to cooperate with their fellow teachers to develop conditions that foster a more mutual commitment to learning. Teachers should be trained to improve their learning involvement. Stressing creative thinking abilities is crucial to enhance the capacity of pupils to build their knowledge. Teachers 
should thus allow pupils to improve their research abilities [33]. Teacher training must be conducted to teach students how to grasp interconnected ideas in daily life by raising HOTS inquiries.

\subsection{Elaborative}

Elaborative is an aspect of creative thinking skills. In this aspect, it has been applied in face-to-face and online learning, basically, the ability of students to provide detailed or elaborative explanations when learning heat material face-to-face and online. All students have this ability. Students have not been able to solve problems that contain limited information by practising science concepts during learning. The following are the results of the student's answers to the questionnaire about creative thinking skills in the elaborative aspect, presented in the following graph:

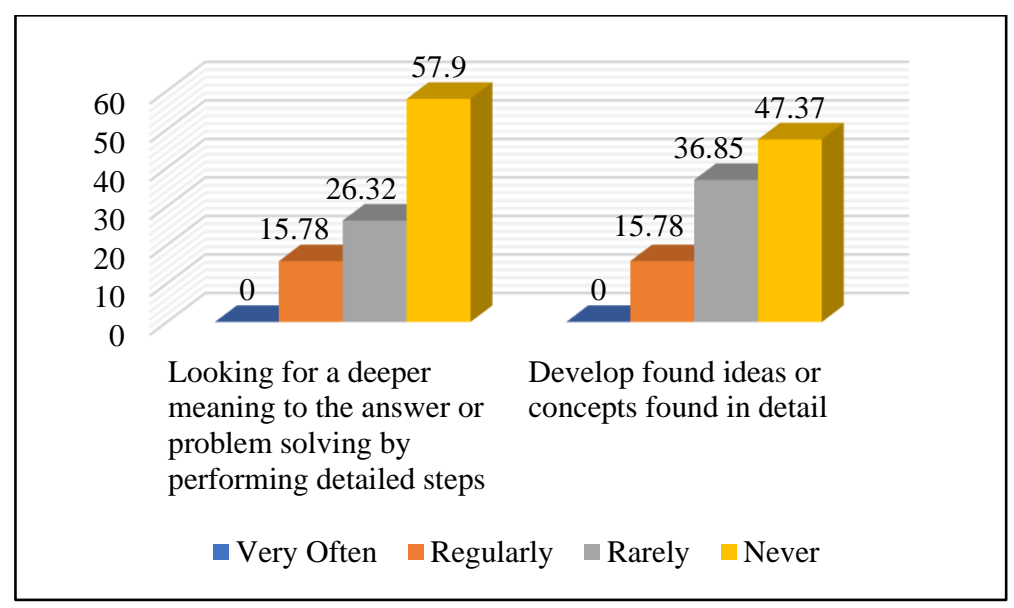

Fig. 5. Results of students' questionnaire answers on the elaborative aspect

The highest percentage of flexible aspects in the graph above is the indicator of choice never with a rate of $52.63 \%$. When learning science with a blended learning system, the elaborative elements have not been well integrated. Meanwhile, in the overall learning of creative thinking skills, the elaborative aspect is $24.60 \%$.

Students have not explained coherently and in detail from one level to another, especially during the experiment or the experimental process. Students can not look for a deeper meaning to the answer or problem solving by taking detailed steps on science material questions because they do not detail the discovery process. Solutions that can be applied in a way that students can explain coherently and in fact from one level to another, especially during the experiment or the experimental process. Face-to-face learning begins with telling stories or events in everyday life, both inside and outside the book. The teacher provides opportunities for students to answer questions or express their opinions [39]. Teachers can discuss concept learning material, determine issues, formulate problems, present literature studies, present frames, present hypotheses, and develop research methods, including research parameters and tools for research, current research flow chart and data processing techniques, and analysis techniques. These are 
all components that matter. We can observe how challenges may be formulated and solved and how the advantages of research are communicated in life. Creativity may be an indigenous feature but may also be improved in the classroom through any means, and educators must include activities that foster the creativeness of teachers [28]. Students could not discover comprehensive procedures to create a logical conclusion. Teachers may begin learning via things in their lives and offer students the opportunity to voice their ideas.

Students have not been able to develop ideas or concepts found in detail and only mention what they know from the learning process without linking them to what is in the book to explain the development of ideas. Constraints are most likely due to a science learning experience that uses a blended learning system with a limited time. Learning should be able to help students to actualize their understanding of science learning. Students will more easily understand it if learning activities are linked to real-world situations. They are strengthening concepts by reading before learning. The curiosity of students will develop so that there is an increase in skills in creative thinking. Solutions to enhance creative thinking, teachers can generate many ideas and thoughts on a topic or problem, explore different points of view, and then reshape or simplify concepts, increasing open-mindedness tolerance for fantastic and entertaining ideas and creative thinking chances. Combine and develop them. Ideas. In addition, helping to express educated, flexible ideas successfully and have an excellent educational role [40]. Educators also have to monitor and manage the circumstances of learning even after face-to-face instruction is done. Educators can still use online courses to allow teachers to study the material before (offline) learning and require technology-based learning strategies [41]. Students could not generate ideas to enhance a concept. Teachers provided insights and opinions on a subject or issue to examine students' diverse perspectives and redefine or simplify the idea and openness.

\section{Conclusion}

Integrating creative thinking skills in science learning with applying the blended learning system in elementary schools is low. Various obstacles cause this, namely limited learning difficulties, developing new thoughts, writing answers to similar books, answering non-detailed questions. Efforts that can be implemented are apperception, freedom of discussion during online and face-to-face learning, development of learning towards life relevant to High Order Thinking Skill (HOTS) questions, strengthening concepts by reading before learning, and maximizing WhatsApp features including video calls and voice notes.

Acknowledgements. The authors would like to thank the principal, teachers, and students of the State Mutiara Islamic Elementary School Boyolali.

\section{References}

[1] W. A. F. Dewi, "Dampak COVID-19 terhadap Implementasi Pembelajaran Daring di Sekolah Dasar," Edukatif J. Ilmu Pendidik., vol. 2, no. 1, hal. 55-61, 2020, doi: 10.31004/edukatif.v2i1.89.

[2] N. A. Syamsul Bahri, "Analisis Manajemen Sdm Dalam Mengembangkan,” J. Islam. Educ., vol. 1, no. 1, hal. 20-40, 2020.

[3] Y. Fitriyani, I. Fauzi, dan M. Z. Sari, "Motivasi Belajar Mahasiswa Pada Pembelajaran Daring Selama Pandemik Covid-19," Profesi Pendidik. Dasar, vol. 7, no. 1, hal. 121-132, 2020, doi: 10.23917/ppd.v7i1.10973. 
[4] D. N. Harris dan M. F. Larsen, "The effects of the New Orleans post-Katrina market-based school reforms on student achievement, high school graduation, and college outcomes," Educ. Res. Alliance, vol. 1, no. 1, hal. 1-71, 2018.

[5] L. Dewi, "Rancangan Program Pembelajaran Daring Di Perguruan Tinggi: Studi Kasus Pada Mata Kuliah Kurikulum Pem-Belajaran Di Universitas Pendidikan Indonesia," Edutech, vol. 16, no. 2, hal. 205, 2017, doi: 10.17509/e.v16i2.7616.

[6] Y. Irawan, N. Susanti, dan W. A. Triyanto, "Analisa Dan Perancangan Sistem Pembelajaran Online (E-Learning) Pada Smk Mambaul Falah Kudus," Simetris J. Tek. Mesin, Elektro dan Ilmu Komput., vol. 6, no. 2, hal. 345, 2015, doi: 10.24176/simet.v6i2.471.

[7] B. H. Susanti, "Penggunaan Media Online Dalam Proyek Pembuatan Bahan Ajar Berbasis Web Pada Mata Kuliah Zoologi Vertebrata," Edusains, vol. 11, no. 1, hal. 21-28, 2019, doi: 10.15408/es.v11i1.7728.

[8] W. Bao, "COVID -19 and online teaching in higher education: A case study of Peking University ," Hum. Behav. Emerg. Technol., vol. 2, no. 2, hal. 113-115, 2020, doi: 10.1002/hbe2.191.

[9] L. D. Herliandry, N. Nurhasanah, M. E. Suban, dan H. Kuswanto, "Pembelajaran Pada Masa Pandemi Covid-19," JTP - J. Teknol. Pendidik., vol. 22, no. 1, hal. 65-70, 2020, doi: 10.21009/jtp.v22i1.15286.

[10] A. Syakur, Z. Fanani, dan R. Ahmadi, "The Effectiveness of Reading English Learning Process Based on Blended Learning through 'Absyak' Website Media in Higher Education," Budapest Int. Res. Critics Linguist. Educ. J., vol. 3, no. 2, hal. 763-772, 2020, doi: 10.33258/birle.v3i2.927.

[11] I. W. Redhana, "Mengembangkan Keterampilan Abad Ke-21 Dalam Pembelajaran Kimia," J. Inov. Pendidik. Kim., vol. 13, no. 1, 2019.

[12] W. Wahyudi, "The effectiveness of sharing blended project based learning (SBPBL) model implementation in operating system course," Int. J. Emerg. Technol. Learn., vol. 15, no. 5, hal. 202-211, 2020, doi: 10.3991/IJET.V15I05.11266.

[13] R. Septikasari dan R. N. Frasandy, "Keterampilan 4C Abad 21 dalam Pembelajaran Pendidikan Dasar," Tarb. Al-Awlad, vol. VIII, no. 2, hal. 112-122, 2018.

[14] M. G. Erikson dan M. Erikson, "Learning outcomes and critical thinking-good intentions in conflict," Stud. High. Educ., vol. 44, no. 12, hal. 2293-2303, 2019, doi: 10.1080/03075079.2018.1486813.

[15] D. Indraswati, D. A. Marhayani, D. Sutisna, A. Widodo, dan M. A. Maulyda, "Critical Thinking Dan Problem Solving Dalam Pembelajaran Ips Untuk Menjawab Tantangan Abad 21," Sos. Horiz. J. Pendidik. Sos., vol. 7, no. 1, hal. 12, 2020, doi: 10.31571/sosial.v7i1.1540.

[16] L. Sugiyarti, A. Arif, dan Mursalin, "Pembelajaran Abad 21 di SD," Pros. Semin. dan Disk. Nas. Pendidik. Dasar, hal. 439-444, 2018.

[17] J. Lennox, N. Reuge, dan F. Benavides, "UNICEF's lessons learned from the education response to the COVID-19 crisis and reflections on the implications for education policy," Int. J. Educ. Dev., hal. 102429, 2021, doi: 10.1016/j.ijedudev.2021.102429.

[18] S. J. Seage dan M. Türegün, "The effects of blended learning on STEM achievement of elementary school students," Int. J. Res. Educ. Sci., vol. 6, no. 1, hal. 133-140, 2020, doi: 10.46328/ijres.v6i1.728.

[19] I. K. Widiara, "Blended Learning Sebagai Alternatif Pembelajaran Di Era Digital," Purwadita, vol. 2, no. 2, hal. 50-56, 2018.

[20] Reflianto dan Syamsuar, "Pendidikan dan Tantangan Pembelajaran Berbasis Teknologi Informasi di Era Revolusi Industri 4.0," J. Ilm. Teknol. Pendidik., vol. 6, no. 2, hal. 1-13, 2018.

[21] J. Kacetl dan I. Semradova, "Reflection on blended learning and e-learning - case study," Procedia Comput. Sci., vol. 176, hal. 1322-1327, 2020, doi: 10.1016/j.procs.2020.09.141.

[22] P. Wannapiroon, "Development of Research-based Blended Learning Model to Enhance Graduate Students' Research Competency and Critical Thinking Skills," Procedia - Soc. Behav. Sci., vol. 136, hal. 486-490, 2014, doi: 10.1016/j.sbspro.2014.05.361.

[23] I. K. Suartama, P. Setyosari, Sulthoni, dan S. Ulfa, "Development of an instructional design model for mobile blended learning in higher education," Int. J. Emerg. Technol. Learn., vol. 14, no. 16, hal. 4-22, 2019, doi: 10.3991/ijet.v14i16.10633. 
[24] W. Sumarni dan S. Kadarwati, "Ethno-stem project-based learning: Its impact to critical and creative thinking skills," J. Pendidik. IPA Indones., vol. 9, no. 1, hal. 11-21, 2020, doi: 10.15294/jpii.v9i1.21754.

[25] P. G. Rivas, "Strategies for Teaching and Dissemination of Artistic Heritage by Promoting Critical and Creative Thinking Among Future Primary Education Teachers," Procedia - Soc. Behav. Sci., vol. 237, hal. 717-722, 2017, doi: 10.1016/j.sbspro.2017.02.112.

[26] C. Yildiz dan T. Guler Yildiz, "Exploring the relationship between creative thinking and scientific process skills of preschool children," Think. Ski. Creat., vol. 39, no. January, hal. 100795, 2021, doi: $10.1016 /$ j.tsc.2021.100795.

[27] S. Sophonhiranrak, P. Suwannatthachote, dan S. Ngudgratoke, "Factors Affecting Creative Problem Solving in the Blended Learning Environment: A Review of the Literature," Procedia Soc. Behav. Sci., vol. 174, no. 1982, hal. 2130-2136, 2015, doi: 10.1016/j.sbspro.2015.02.012.

[28] Yustina, W. Syafii, dan R. Vebrianto, "The effects of blended learning and project-based learning on pre-service biology teachers' creative thinking skills through online learning in the COVID-19 pandemic," J. Pendidik. IPA Indones., vol. 9, no. 3, hal. 408-420, 2020, doi: 10.15294/jpii.v9i3.24706.

[29] A. R. Sya'Roni, P. A. Inawati, E. Guswanto, Susanto, dan Hobri, "Students' creative thinking skill in the flipped classroom-blended learning of mathematics based on lesson study for learning community," J. Phys. Conf. Ser., vol. 1563, no. 1, 2020, doi: 10.1088/1742-6596/1563/1/012046.

[30] N. Songkram, "E-learning System in Virtual Learning Environment to Develop Creative Thinking for Learners in Higher Education," Procedia - Soc. Behav. Sci., vol. 174, hal. 674-679, 2015, doi: 10.1016/j.sbspro.2015.01.600.

[31] U. A. Daulay, S. Syarifuddin, dan B. Manurung, "Pengaruh Blended Learning Berbasis Edmodo dan Motivasi Belajar Terhadap Hasil Belajar IPA Biologi dan Retensi Siswa pada Sistem Peredaran Darah Manusia di Kelas VIII SMP Negeri 5 Medan,” J. Pendidik. Biol., vol. 6, no. 1, hal. 260-266, 2016, doi: 10.24114/jpb.v6i1.4330.

[32] M. van Hooijdonk, T. Mainhard, E. H. Kroesbergen, dan J. van Tartwijk, "Creative Problem Solving in Primary Education: Exploring the Role of Fact Finding, Problem Finding, and Solution Finding across Tasks," Think. Ski. Creat., vol. 37, no. April, hal. 100665, 2020, doi: 10.1016/j.tsc.2020.100665.

[33] S. Srikoon, T. Bunterm, T. Nethanomsak, dan K. N. Tang, "Effect of 5P model on academic achievement, creative thinking, and research characteristics," Kasetsart J. Soc. Sci., vol. 39, no. 3, hal. 488-495, 2018, doi: 10.1016/j.kjss.2018.06.011.

[34] S. Humble, P. Dixon, dan E. Mpofu, "Factor structure of the Torrance Tests of Creative Thinking Figural Form A in Kiswahili speaking children: Multidimensionality and influences on creative behavior," Think. Ski. Creat., vol. 27, no. November 2016, hal. 33-44, 2018, doi: 10.1016/j.tsc.2017.11.005.

[35] H. Sahidu, A. Harjono, M. Yeni, F. Keguruan, U. Mataram, dan M. Fisikapesertadidik, "Pengaruh pembelajaran berbasis proyek dengan virtualmediaassistance," hal. 167-179.

[36] A. K. Bhowmik, M. S. McCaffrey, A. M. Ruskey, C. Frischmann, dan O. Gaffney, "Powers of 10: Seeking' sweet spots' for rapid climate and sustainability actions between individual and global scales," Environ. Res. Lett., vol. 15, no. 9, 2020, doi: 10.1088/1748-9326/ab9ed0.

[37] A. Permanasari, "STEM Education: Inovasi dalam Pembelajaran Sains," Semin. Nas. Pendidik. Sains, hal. 23-34, 2016.

[38] K. C. Suryandari, Sajidan, S. B. Raharjo, Z. K. Prasetyo, dan S. Fatimah, "Pengaruh Pembelajaran Sains Berbasis Proyek Terhadap Keterampilan Literasi Ilmu dan Pemikiran Kreatif Calon Guru," Cakrawala Pendidik., vol. XXXVII, no. 3, hal. 345-355, 2018.

[39] E. Sujarwo dan T. N. H. Yunianta, "Analisis Kemampuan Berpikir Kreatif Siswa Kelas VIII SMP Dalam Menyelesaikan Soal Luas Bangun Datar,” J. Kaji. Pembelajaran ..., vol. 2, no. April, hal. 1-9, 2018, [Daring]. Tersedia pada: http://journal2.um.ac.id/index.php/jkpm/article/view/2874.

[40] C. Dziuban, C. R. Graham, P. D. Moskal, A. Norberg, dan N. Sicilia, "Blended learning: the new normal and emerging technologies," Int. J. Educ. Technol. High. Educ., vol. 15, no. 1, hal. 1-16, 2018, doi: 10.1186/s41239-017-0087-5. 
[41] Z. Zainuddin dan C. M. Keumala, "Blended Learning Method Within Indonesian Higher Education Institutions," J. Pendidik. Hum., vol. 6, no. 2, hal. 69-77, 2018, [Daring]. Tersedia pada: http://journal.um.ac.id/index.php/jphpISSN:2338-8110/eISSN:2442-3890. 